\title{
Computer guided surgery in the maxillary esthetic zone
}

\section{Cirurgia guiada por computador em área estética da maxila}

\author{
Jéssica Lemos GULINELLI1 iD https://orcid.org/0000-0001-7113-2017 \\ Thiago CALCAGNOTTO1 ID https://orcid.org/0000-0002-8265-5486

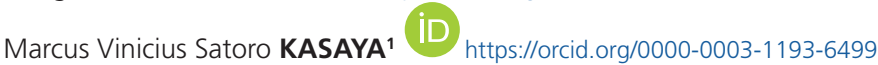 \\ Caio Peres BELLATO2 ${ }^{2}$ iD https://orcid.org/0000-0003-1565-3453 \\ Eduardo Sanches GONÇALES ${ }^{2}$ iD https://orcid.org/0000-0002-6682-7006 \\ Pâmela Letícia dos SANTOS ${ }^{3}$ iD https://orcid.org/0000-0003-1734-4187
}

\section{ABSTRACT}

This clinical report describes the implant rehabilitation for the treatment of pathological roots resorption due to inadequate orthodontic movement in prosthetic space reduced by means of load and immediate implants, computer-guided surgery and use of the own tooth crown in a 21-year-old-patient. The atraumatic exodontics of the right and left upper lateral incisors was performed, and then immediate placement of osseointegrated implants using the computer guided surgery technique. The crown teeth itself was used in the immediate aesthetic and functional rehabilitation. Completion of the treatment resulted in a functional and aesthetic successful outcome and a 27 months follow-up presented uneventful. The procedures included in this complex rehabilitation treatment in the esthetic zone were appropriate and essential for the maintenance of the soft and hard tissues contour and thickness ensuring the excellence in rehabilitation.

Indexing terms: Dental implants. Esthetics. Osseointegration. Oral rehabilitation.

\section{RESUMO}

Este relato de caso clínico descreve a reabilitação com implantes para o tratamento da reabsorção radicular patológica devido à movimentação ortodôntica inadequada em espaço protético reduzido, por meio implante imediato e carga imediata, pela técnica da cirurgia guiada por computador e uso da própria coroa dentária, em paciente de 21 anos. A exodontia atraumática dos incisivos laterais superiores direito e esquerdo foi realizada, em seguida realizou-se a instalação imediata dos implantes osseointegráveis, utilizando a técnica de cirurgia guiada por computador. Os próprios dentes da coroa foram usados na reabilitação estética e funcional imediata. A conclusão do tratamento resultou em sucesso funcional e estético com acompanhamento de 27 meses sem intercorrências. Os procedimentos incluídos neste complexo tratamento de reabilitação na zona estética foram adequados e essenciais para a manutenção do contorno e espessura dos tecidos moles e duros garantindo a excelência na reabilitação.

Termos de Indexação: Implante dental. Estética. Osseointegração. Reabilitação oral.

$\checkmark v \nabla$

${ }^{1}$ Centro Universitário do Sagrado Coração, Curso de Odontologia, Departamento de Ciências da Saúde. Bauru, SP, Brasil.

2 Universidade de São Paulo, Faculdade de Odontologia de Bauru, Departamento de Cirurgia, Patologia, Radiologia e Estomatologia. Alameda Dr. Octávio Pinheiro Brisolla, 9-75 - Vila Regina, Bauru - SP, 17012-230. Bauru, SP, Brasil. Correspondence to: CP BELLATO. E-mail: <caiobellato@hotmail.com>.

3 Universidade de Araraquara. Curso de Odontologia. Departamento de Pós-Graduação em Ciências Odontológicas. Araraquara, SP, Brasil.

$\boldsymbol{v} \boldsymbol{v} \boldsymbol{v}$

How to cite this article

Gulinelli JL, Calcagnotto T, Kasaya MVS, Bellato CP, Gonçales ES, Santos PL. Computer guided surgery in the maxillary esthetic zone. RGO, Rev Gaúch Odontol. 2021;69:e20210033. http://dx.doi.org/10.1590/1981-86372021003320200172 


\section{INTRODUCTION}

The use of osseointegrated implants in the region of the Upper Lateral Incisors (ULI) is complex in many cases [1]. Therefore, there is a need for an appropriate reverse planning, as well as the use of techniques that ensure the success of the rehabilitation and maintenance of the soft tissues, such as the proper selection of the implant diameter, the placement of implants in areas after exodontics, fillings of peri-implant gaps with biomaterials, the computerguided surgery without flaps and the possibility of the immediate loading [2].

The placement of dental implants with a reduced diameter, in cases with little osseous volume in thickness and height and a shortage of the mesial distal space, shows a favorable prognosis for the ULI agenesis treatment as it favors the existence of, at least, 1 millimeter of alveolar bone around the implant [3-7].

In the immediate implant or after exodontics, the treatment time is reduced, the bone resorption is minimized, optimizing the function and aesthetics since the first surgical procedure, and the patient presents a bigger satisfaction as the psychological tension is reduced and a second surgical procedure for the implant placement is eliminated. However, some particularities are necessary for a greater predictability in this type of treatment: preserved buccal bone, minimally invasive exodontics preserving buccal bone plate and adjacent soft tissues, presence of proximal bone for the aesthetics of the papillas and the need for filling the marginal gap resultant between the implant surface and the host bone. Among the biomaterials used, the mineralized bovine bone matrix is highlighted $[8,9]$.

The association of the computer-guided surgery with the absence of flaps arose as an effective alternative in dental implantology with several advantages, such as the preservation of the bone tissue volume around the implants, the reduction of the surgical time, the increase of the patient comfort, the reduction of bleeding, edema and postoperative pain, as well as the faster recovery from the surgical procedure [10-12]. There are authors [13] who suggest the propriety of the surgical procedure without flaps in the aid of soft tissue maintenance, including the gingival edges and the dental papillas.

The guided surgery is quite focused on unitary cases. In unitary cases involving the aesthetics region, there should be at least $1.5 \mathrm{~mm}$ of bone around the complete cervical portion of the implant, which should be subcrestal. The distance from the dental contact point to the bone crest must be of at most $5 \mathrm{~mm}$ [14]. Care in the dental apical region is necessary because these areas are responsible for the innervation and vasculature of the tooth, requiring greater distances for implants [15].

This study is aimed at reporting a clinical case for the treatment of pathological roots resorption due to orthodontic movement in prosthetic space reduced by means of load and immediate implants, computerguided surgery and use of the own tooth crown for the manufacture the provisional and definitive restoration.

\section{CASE REPORT}

The 21-year-old female patient, D. S., leucoderma, with a good general health condition looked for treatment due to sensitivity in the anterior teeth. The patient reported she had already done orthodontic treatment with fixed orthodontic braces for about 2 years ago (figure 1). Initially, periapical radiographs were performed in which it was possible to verify the root resorption of the dental structures 12 and 22 . Through the cone beam computed tomographic (CBCT) analysis, a significant reabsorption at the root apex region of the teeth 12 and 22 became clear (figure 2).

After the assessments carried out by professionals, experts in implantology, surgery and dental prosthesis, the extraction of the teeth 12 and 22 and the immediate osseointegrated implant placement were planned through virtual planning and guided surgery. Previously to surgical procedure, the reverse planning was performed and the rehabilitation treatment was defined.

The patient presented, according to the clinical examination analysis, apparently lined and leveled teeth. It was also possible to check a good mouth opening, a sufficient quantity of keratinized mucosa and adequate bone availability for the performance of the procedures required for the treatment with the Neoguide ${ }^{\circledR}$ guided surgical technique. Her medical history did not include any systematic contraindications to either implant or regenerative surgery. Therefore, a molding of the patient was performed with condensation silicone for the treatment planning. Then, the bite registration was performed with silicone to establish the initial position of the tooth for 

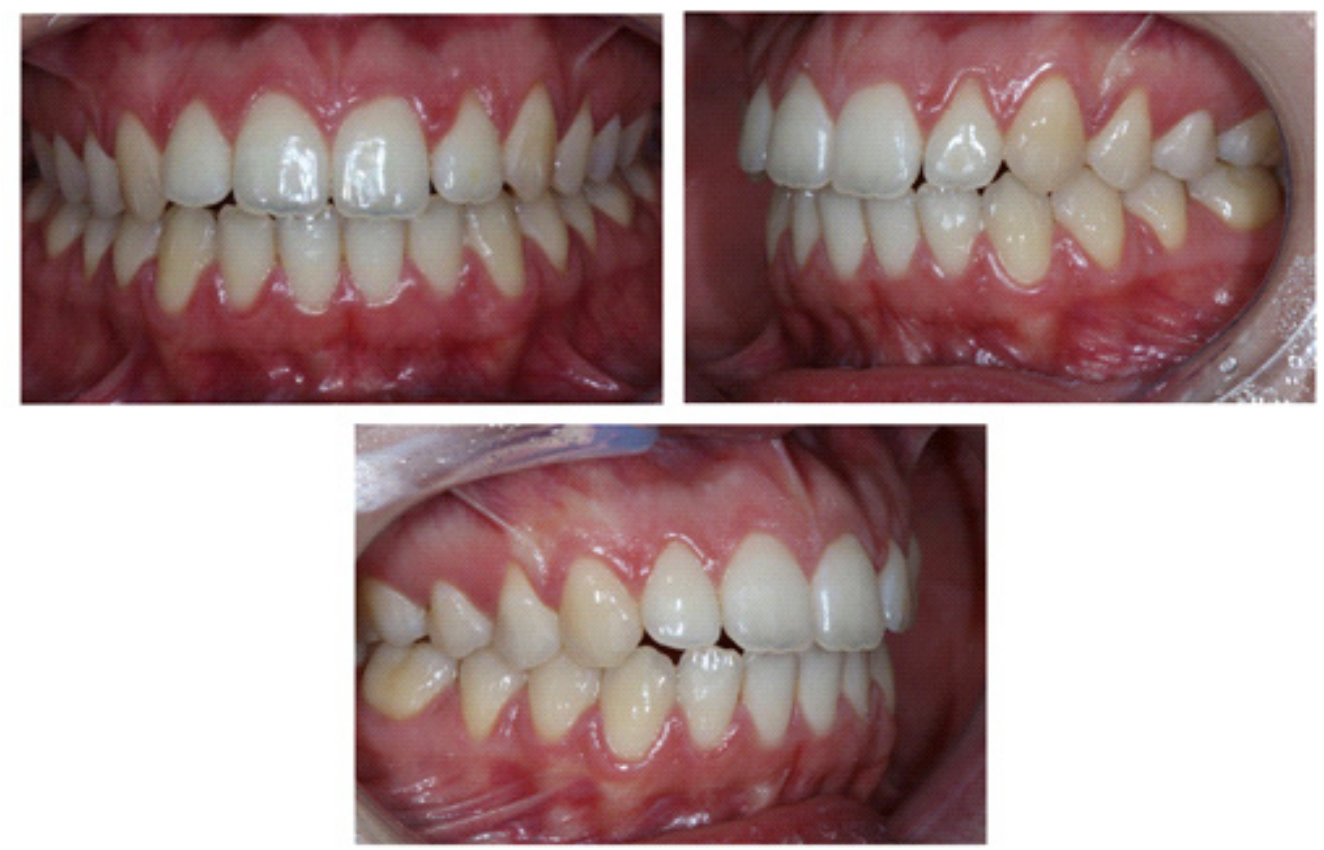

Figure 1. Pre treatment clinical appearance - front e lateral view. $404 \times 235 \mathrm{~mm}(72 \times 72 \mathrm{DPI})$.

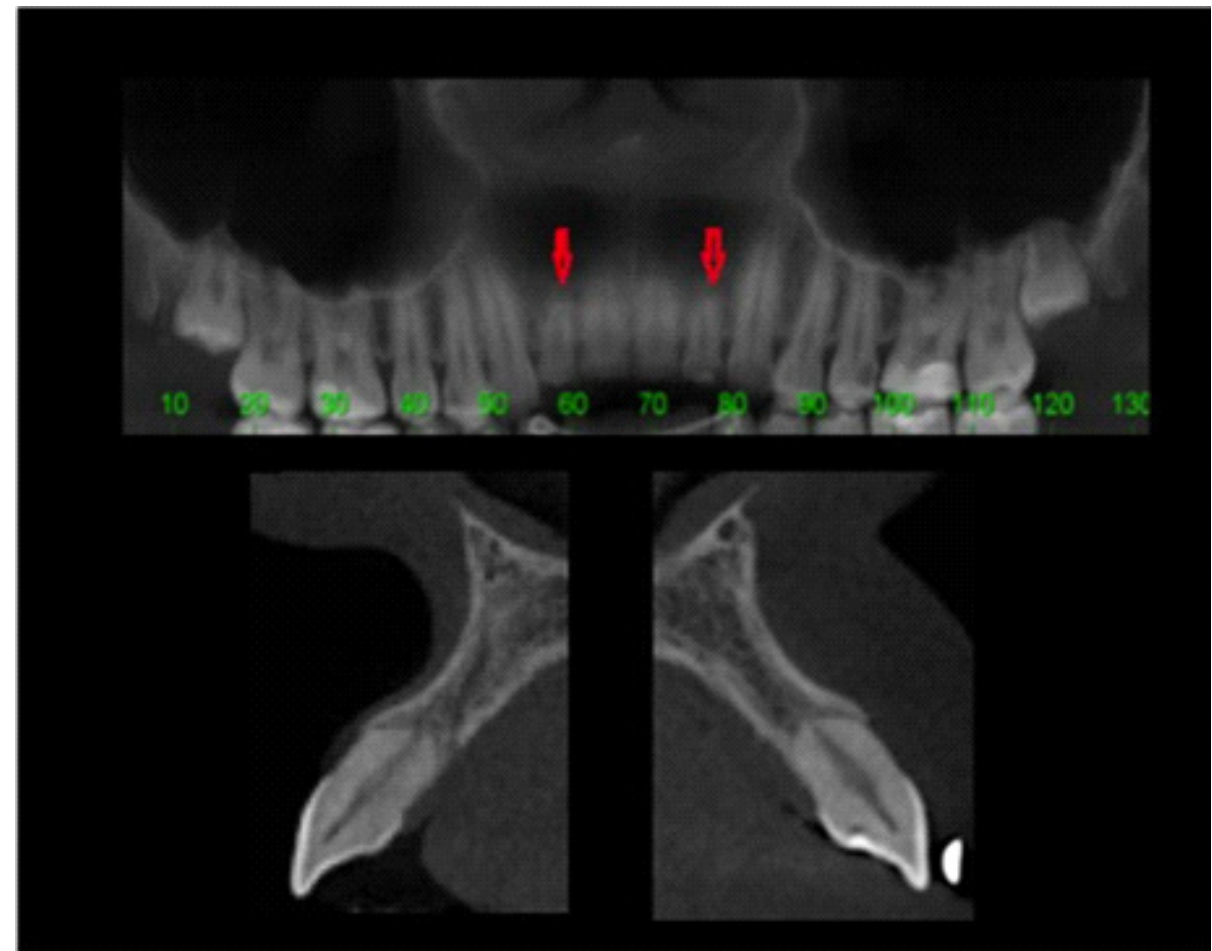

Figure 2. Initial computed tomography: dental structures 12 and 22. Notice the root resorption at the apical region (narrows). $175 \times 139 \mathrm{~mm}$ (72 x 72 DPI)

the manufacture of the temporary (figure 3). The patient signed an informed consent form before surgery.
The surgical preparation started by intra and extraoral antisepsis. All procedures were performed under local 

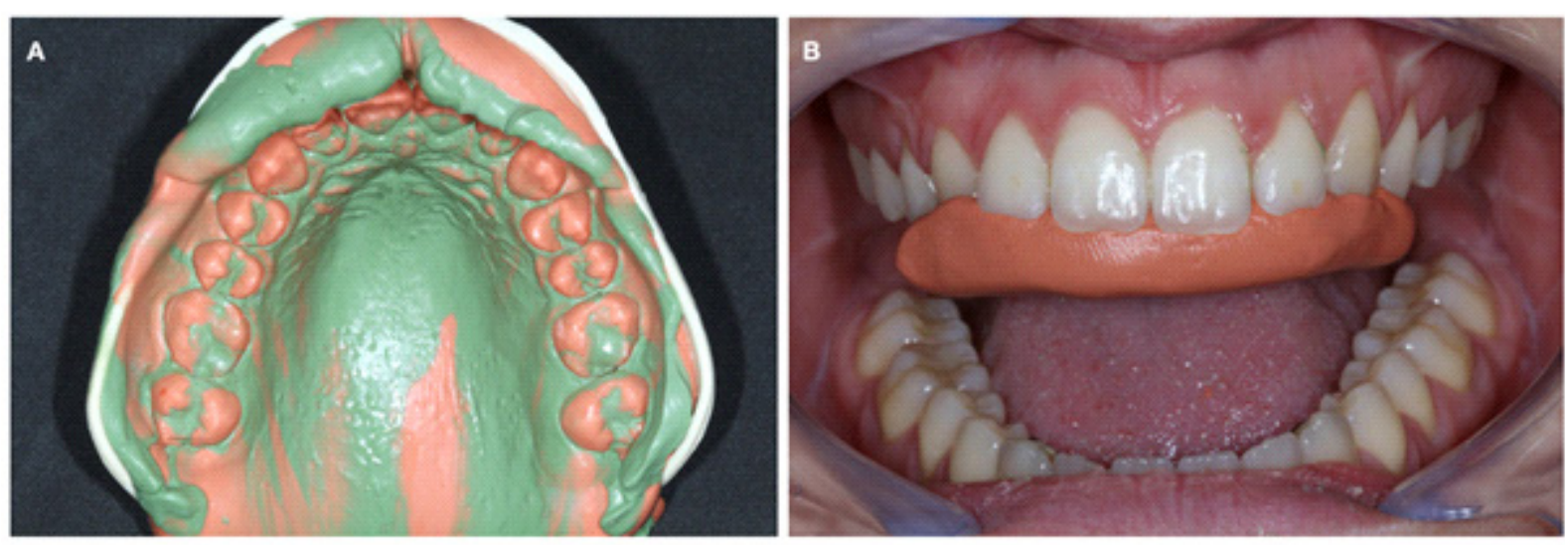

Figure 3. A, Molding of the patient with condensation silicone for the treatment planning. B, Bite registration with silicone to estabilish the initial position of the teeth for the provisional prosthesis. $382 \times 235 \mathrm{~mm}(72 \times 72 \mathrm{DPI})$.

anaesthesia with infiltration of articaine hydrochloride $4 \%$ with epinephrine 1:200,000 (Nova DFL ${ }^{\circledR}$, Rio de Janeiro, Brazil) at the bottom of the vestibule, complemented by palatine. The extraction of teeth 12 and 22 was performed was minimally invasive using the periotome (Periotomo \#1, Quinelato $^{\circledR}$, Brazil) preserving architecture of the alveolar socket (figure $4 \mathrm{~A}$ ). After the extractions and no vertical loss of the socket walls, including the buccal bone, the surgery guide was adapted and fixed on the adjacent teeth, enabling the beginning of the surgical instrumentation (figure 4B). Respecting the progressive sequence of the drills, the spear drill was used initially, followed by the $2.0 \mathrm{~mm}$ and $2.8 \mathrm{~mm}$ drill with the respective guide, the drills speed varied from 400 to 600 rpm with copious saline irrigation. The implant
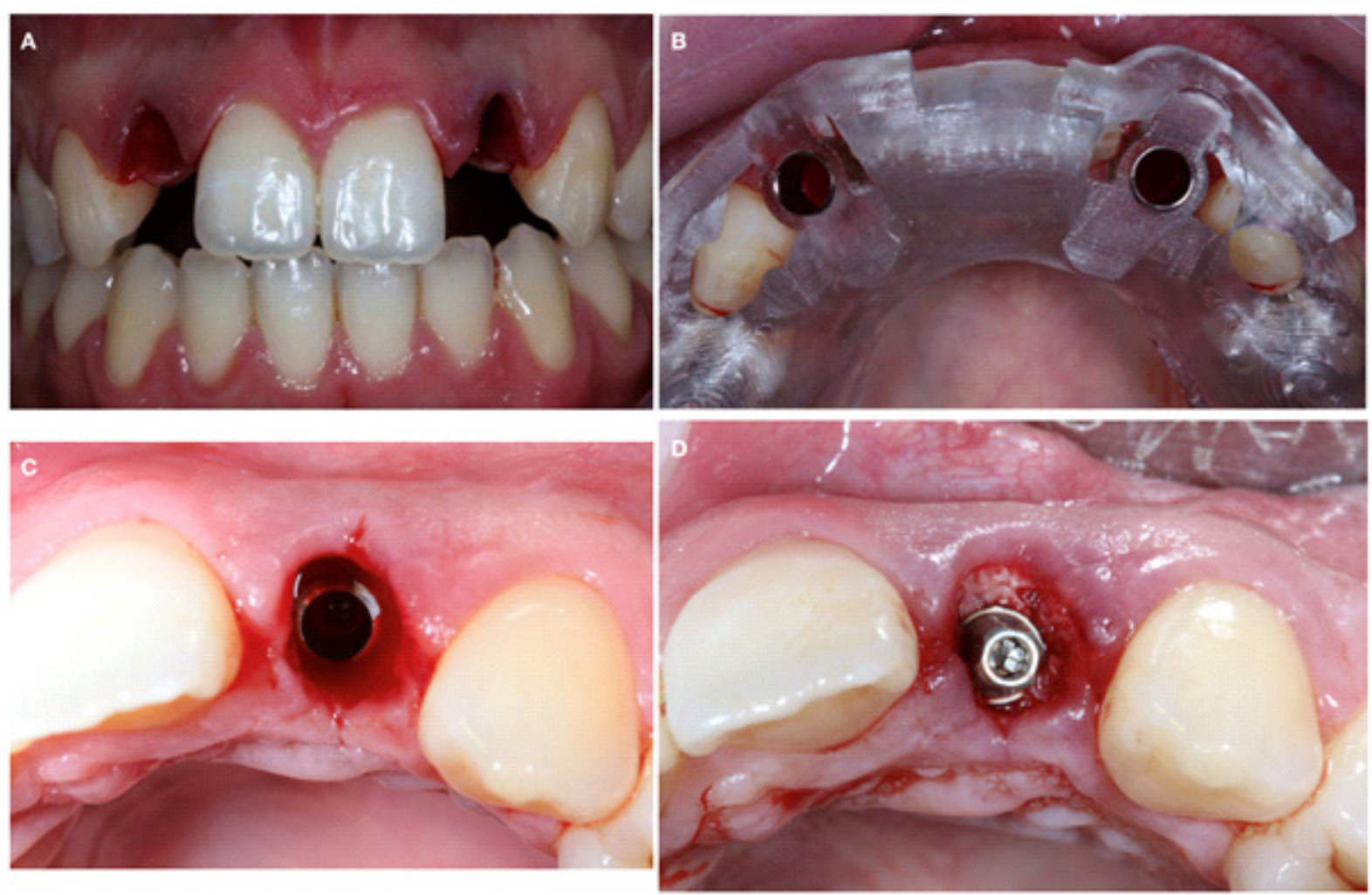

Figure 4. A, Preservation of architecture the alveolar socket after the extraction. B, Surgical guide positioned. C, Implant installation. D, Adapted abutment and filling the gap with Bio-Oss $\circledast$. 419×235mm (72 x 72 DPI) 
used in the region of the tooth 12 was the Drive Cone Morse ${ }^{\circledR} 3.5 \times 16 \mathrm{~mm}$ (Neodent, Curitiba, Brazil) and, in the region of the tooth 22, it was the Drive Cone Morse ${ }^{\circledR} 3.5$ $\times 13 \mathrm{~mm}$ (Neodent, Curitiba, Brazil). Both had a adequate primary stability at the insertion moment with 45 Newtons and correct tridmensional position (figure 4C).

After placing the implants, the surgical guide was removed and the abutments were adapted. The abutment $(3.3 \times 4 \times 2.5 \mathrm{~mm})$ in the implants 12 and the abutment $(3.3 \times 6 \times 1.5 \mathrm{~mm})$ in the implant 22 . The marginal space between the implant and the buccal bone (gap) was verified, in which there was the necessity of filling with biomaterial Bio-Oss ${ }^{\circledR}$ (Geistlich, Wolhusen, Sweden) (figure 4D). To obtain the provisional prostheses, the acrylic cylinder universal abutment was placed directly on the abutment carried out the positioning in the mouth of the coronary part of the worn tooth and the fixation with fluid composite resin in the acrylic cylinder, enabling the capture of the assembly (acrylic-resin-part coronary cylinder) (figure 5A). The empty spaces were filled with composite resin. The provisional prostheses from the patient's tooth were adjusted according to the initial registration of their own bite, allowing them to stay in the same starting position (figure 5B).
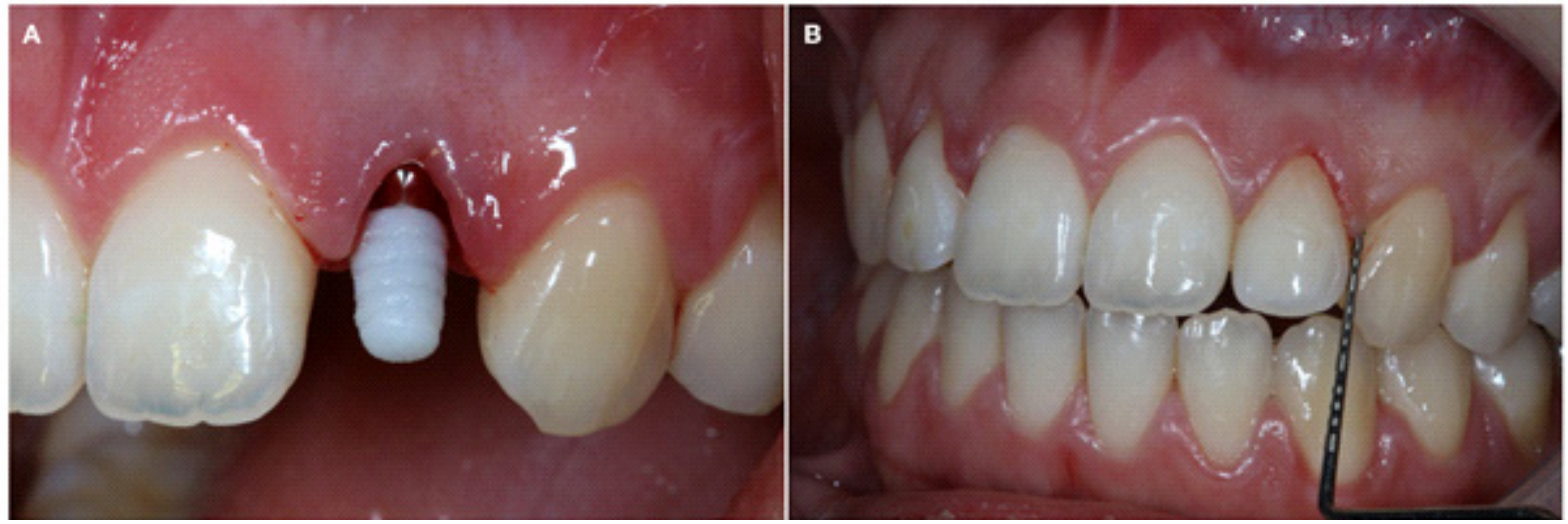

Figure 5. A, Installation of the acrylic cylinder universal abutment. B, Temporarie prosthesis installed.

The provisional crowns were subjected to an occlusal adjustment in protrusion and right and left laterality, leaving them in infra-occlusion, in order to ensure the proper distribution of the occlusal forces.

In the immediate postoperative period, antibiotics (500mg amoxicillin, three times daily for seven days), nonsteroidal anti-inflammatory (400mg ibuprofen, three times daily for three days) and analgesic (500mg paracetamol, in case of pain), were prescribe. Besides, the patient was asked to carry out the topical usage of chlorhexidine digluconate at $0.12 \%$ for mouthwash, three times a day, after oral hygiene, for seven days.

After period of osseointegration, six months, it was explained the patient the need to make the final prosthesis and your importance, however, due to unsatisfactory financial condition and the aesthetics obtained with the provisional prostheses, the patient chose not to perform the permanent prosthesis.
Clinical and CBCT analysis were performed in a 27-months follow-up after implants insertion. Plaque control, gingival sounding, occlusal contacts and mobility were routinely evaluated. No alteration was observed to suggest infection, prosthesis instability and implants mobility (figure 6).

\section{DISCUSSION}

The dental resorption have several factors, which can be physical, chemical and biological $[16,17]$. In the case reported, the patient presented a very advanced radicular resorption, possibly due to the use of orthodontic braces. Therefore, the use of an implant was necessary to replace the teeth that were doomed.

The pre-positioning of the implants and the predictability of the aesthetic and prosthetic function are 

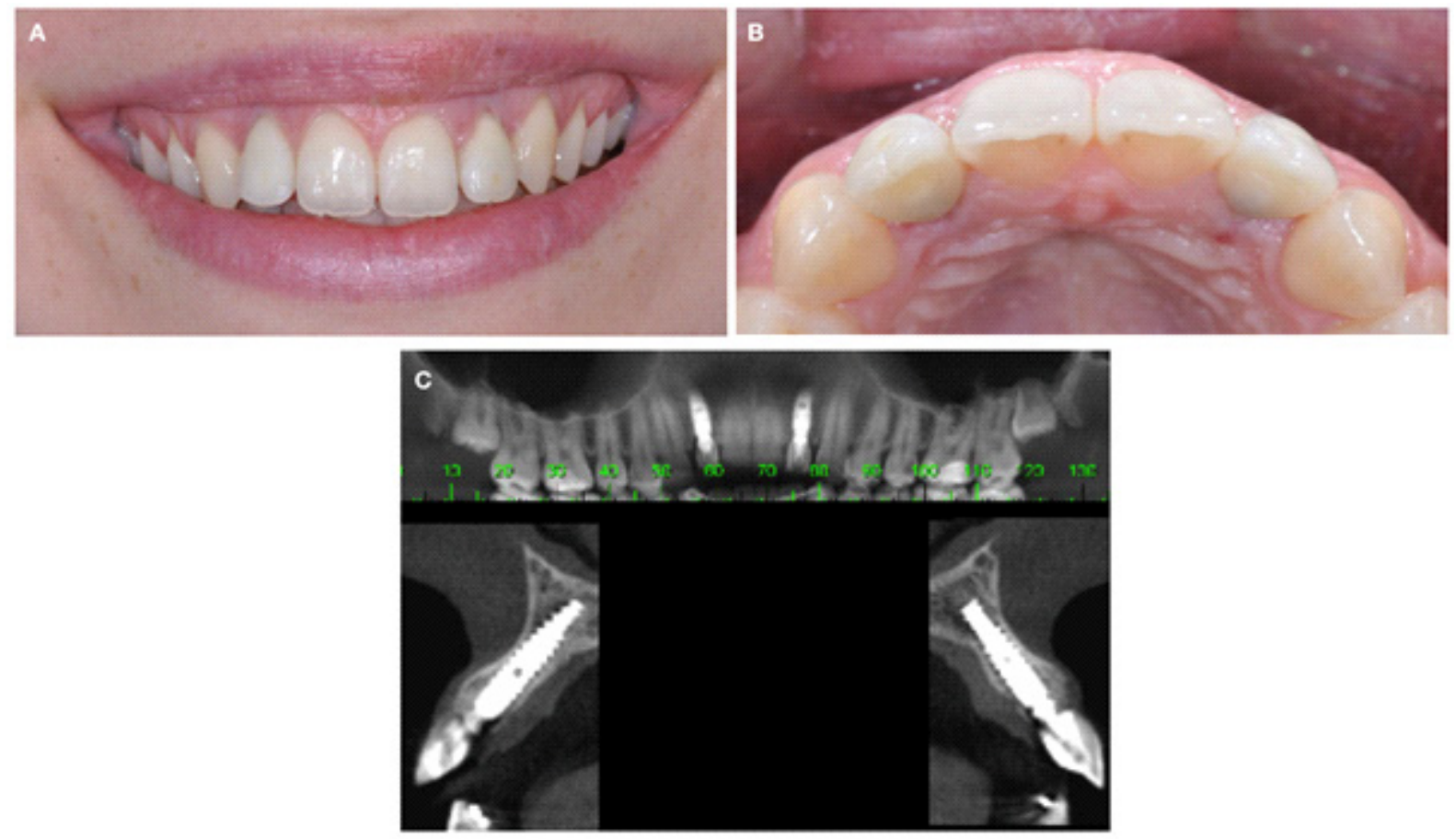

Figure 6. A, Frontal view after twenty seven months. B, Occlusal view after twenty seven months. C, Tomography of Implants 12 and 22 placed with their respective temporary prosthesis. $346 \times 235 \mathrm{~mm}(150 \times 150 \mathrm{DPI})$.

very important factors and very difficult to be defined only with the imaging tests that provide two dimensions. The virtual planning using the computer tomography and the computer guided surgery ensures the fidelity and accuracy in the demarcation of the places of osteotomy and implant placement $[9,18-20]$.

So this guided surgery must be performed, several factors are important, such as, for example, a 4 to $5 \mathrm{~cm}$ mouth opening and a suitable bone quantity. Moreover, the interest of the patient regarding the technique benefits, such as: speed, accuracy, possibility of a better postoperative, although the higher financial cost.

In guided surgeries, in which there is the presence of teeth, the surgical guide will present a better stability, mainly when there is a palatal strengthening also increasing its resistance. Sometimes, the occlusal support is sufficient, other times, the guides need fixing pins to stabilize [14]. In the case reported, the presence of adjacent teeth helped the stability of the guide without the need for fixing pins.

The final position of an unitary implant is defined by several factors: aesthetics, type of prosthetic intermediate, space for the restorative material, gingival phenotype, relation to the surrounding structures (teeth, or restorations) and, finally, quality and amount of remaining bone [14].

The correct positioning of the implant depends on the type of prosthesis that patient will receive (either cemented or screwed) and type of intermediate. Thus, the professional should be visualize the emergence of the prosthetic component in relation to the hyper dense image. It must be remembered that the prosthetic component does not have the same diameter of the implant, so the prosthetic reference for the screw emergence is the spatial center of the "virtual implant." In some cases, it is also possible to observe the limitation of the interproximal space. If this problem occurs, there is an option of a kit for reduced interproximal spaces, which are particularly suitable for unitary $3.5 \mathrm{~mm}$ diameter implants (the smallest diameter option of implants the technique offers).

The placement surgeries immediate after teeth extractions can be planned with softwares even before the surgical procedure. However, during the implant placement, the professional needs to be careful at the moment of the fixation of the implant, as it needs to obtain minimum values of primary stability. The search for such stability is often difficulties since implants stay fixed only by the remaining proximal walls and apex. To ensure a 
better stability, the implant must search an apical anchor of at least 5 to $7 \mathrm{~mm}$. In the case reported, this was taken into account and the primary stability was of $45 \mathrm{~N}$, sufficient for applying the immediate load.

In aesthetic areas, whenever the space between the implant and the bone is greater than $1.5 \mathrm{~mm}$, as in the case described, it is important to fill that space for a better predictability of maintaining the vestibular bone [21]. It was then used bovine mineralized bone matrix (Bio-Oss), as a biomaterial of slow resorption, to fill the gap resulting from the surgical technique of post exodontic implant for having osteoconductive characteristics that favor the formation of new lamellar bone and bone apposition for the implant immediate placing [22-24].

The computer-guided surgery is a fairly predictable technique; however, it has some limitations: the impossibility of visualizing the anatomical structures and the alveolar bone contour, which increases the risk of perforations or fenestrations at cortical or adjacent teeth, increased bone warming due to non-exposure of the tissue, and, thus, the difficulty of bone cooling during osteotomy, the increase of the risk of bad positioning of the implants and the inability to manipulate the soft tissue to ensure an adequate adaptation of keratinized gingival tissue around the implant emergence structures $[24,25]$. It should be performed by qualified professionals with experience in traditional methods of implant therapy.

\section{CONCLUSION}

The results obtained from the literature review and the clinical case, it is possible to conclude the union of the techniques of computer-guided surgery with small diameter exodontic implants in the treatment of agenesis of the maxillary lateral incisor with filling of biomaterial in the host implant-bone spaces, and immediate temporary restoration placement obtained a favorable result as it optimized the function and the aesthetics of the patient.

\section{Collaborators}

JL GULINELLI, performed surgical procedures and followed-up the patient. Final approval. T CALCAGNOTTO, followed-up the patient and managed the study analyses. Final approval. MVS KASAYA, performed prosthetic procedures and followed-up the patient. Manuscript writing. Final approval. CP BELLATO, designed the study and wrote the protocol and the first draft of the manuscript. Critical revision. Final approval. ES GONÇALES, managed the literature searches and wrote the protocol and the first draft of the manuscript. Final approval. PL SANTOS, conception and design of the study. Critical revision. Final approval.

\section{REFERENCES}

1. Bertl K, Grotthoff VS, Bertl MH, Heimel P, Gahleitner A, Ulm C, et al. A wide mesio-distal gap in sites of congenitally missing maxillary lateral incisors is related to a thin alveolar ridge. Clin Oral Implants Res. 2016;3. https://dx.doi.org/10.1111/ clr. 12915

2. Pini NP, de-Marchi LM, Gribel BF, Ubaldini AL, Pascotto RC. Analysis of the golden proportion and width/height ratios of maxillary anterior dentition in patients with lateral incisor agenesis. J Esthet Restor Dent. 2012;24(6):402-414. https:// dx.doi.org/10.1111/j.1708-8240.2012.00533.x

3. Allum SR, Tomlinson RA, Joshi R. The impact of loads on standard diameter, small diameter and mini implants: a comparative laboratory study. Clin Oral Implants Res. 2008;19:553-55.

4. Anitua E, Errazquin JM, de Pedro J, Barrio P, Begoña L, Orive G. Clinical evaluation of Tiny ${ }^{\circledR}$ 2.5- and $3.0-\mathrm{mm}$ narrowdiameter implants as definitive implants in different clinical situations: a retrospective cohort study. Eur J Oral Implantol. 2010;3(4):315-322.

5. Zembić A, Johannesen $L H$, Schou $S$, Malo P, Reichert T, Farella $M$, et al. Immediately restored one-piece single-tooth implants with reduced diameter: One-year results of a multi-center study. Clin Oral Implants Res. 2012;23(1):49-54. https:// dx.doi.org/10.1111/j.1600-0501.2011.02174.x

6. Branzén $M$, Eliasson A, Arnrup K, Bazargani F. Implantsupported single crowns replacing congenitally missing maxillary lateral incisors: A 5-year follow-up. Clin Implant Dent Relat Res. 2015;17(6):1134-1140. https://dx.doi.org/10.1111/cid.12233

7. Garabetyan J, Malet J, Kerner S, Detzen L, Carra MC, Bouchard P. The relationship between dental implant papilla and dental implant mucosa around single-tooth implant in the esthetic area: A retrospective study. Clin Oral Implants Res. 2019;30(12):1229-1237. https://dx.doi.org/10.1111/dr.13536

8. Cosyn J, Eghbali A, Hermans A, Vervaeke S, De Bruyn H, Cleymaet R. A 5-year prospective study on single immediate implants in the aesthetic zone. J Clin Periodontol. 2016 Aug;43(8):702-709. https://dx.doi.org/10.1111/jcpe.12571

9. Yogui FC, Verri FR, de Luna Gomes JM, Lemos CAA, Cruz RS, Pellizzer EP. Comparison between computerguided and freehand dental implant placement surgery: A systematic review and meta-analysis. Int J Oral Maxillofac Surg. $2021 \quad$ Feb;50(2):242-250. https://dx.doi.org/10.1016/j. ijom.2020.08.004

10. Komiyama A, Klinge B, Hultin M. Treatment outcome of immediately loaded implants installed in edentulous jaws following computer-assisted virtual treatment planning and flapless surgery. Clin Oral Implants Res. 2008;19:677-685. 
11. Rocci A, Rocci M, Scoccia A, Martignoni M, Gottlow J, Sennerby L. Immediate loading of maxillary prostheses using flapless surgery, implant placement in predetermined positions, and prefabricated provisional restorations. Part 2: a retrospective 10-year clinical study. Int J Oral Maxillofac Implants. 2012;27(5):1199-1204.

12. Sclar AG. Guidelines for flapless surgery. J Oral Maxillofac Surg. 2008;66:2195-2196.

13. Wat PY, Chow TW, Luk HW, Comfort MB. Precision surgical template for implant placement: a new systematic approach. Clin Implant Dent Relat Res. 2002;4(2):88-92. https://dx.doi. org/10.1111/j.1708-8208.2002.tb00157.x

14. de Siqueira RAC, Fontão FNGK, Sartori IAM, Santos PGF, Bernardes SR, Tiossi R. Effect of different implant placement depths on crestal bone levels and soft tissue behavior: a randomized clinical trial. Clin Oral Implants Res. 2017 Oct;28(10):1227-1233. https://dx.doi.org/10.1111/clr.12946

15. Kaewsiri D, Panmekiate S, Subbalekha K, Mattheos N, Pimkhaokham A. The accuracy of static vs. dynamic computerassisted implant surgery in single tooth space: A randomized controlled trial. Clin Oral Implants Res. 2019;30(6):505-514. https://dx.doi.org/10.1111/clr.13435

16. Topkara A, Karaman Al, Kau CH. Apical root resorption caused by orthodontic forces: A brief review and a long-term observation. Eur J Dent. 2012; 6:445-453.

17. Wang $Y$, He H, Cao Z, Fang Y, Du M, Liu Z. Regulatory effects of bone morphogenetic protein-4 on tumour necrosis factora-suppressed Runx2 and osteoprotegerin expression in cementoblasts. Cell Prolif. 2017;50(4):e12344. https://dx.doi. org/10.1111/cpr.12344

18. Widmann G, Fischer B, Berggren JP, Dennhardt A, Schullian P, Reto $B$, et al. Cone beam computed tomography vs multislice computed tomography in computer-aided design/computerassisted manufacture guided implant surgery based on threedimensional optical scanning and stereolithographic guides:
Does image modality matter? Int J Oral Maxillofac Implants. 2016;31(3):527-533. https://dx.doi.org/10.11607/jomi.4222

19. Jabero $M$, Sarment DP. Advanced surgical guidance technology: A review. Implant Dent. 2006; 15:135-142.

20. Marchack CB, Moy PK. Computed tomography-based, template-guided implant placement and immediate loading: An 8-year clinical report. J Prosthet Dent. 2014;112:1319-1323.

21. Amato F, Amato G, Polara G, Spedicato GA. Guided tissue preservation: Clinical application of a new provisional restoration design to preserve soft tissue contours for singletooth immediate implant restorations in the esthetic area. Int J Periodontics Restorative Dent. 2020;40(6):869-879. https:// dx.doi.org/10.11607/prd.4692

22. Berglundh T, Lindhe J. Healing around implants placed in bone defects treated with Bio-Oss: An experimental study in the dog. Clin Oral Implants Res. 1997; 8:117-124.

23. D'haese J, Ackhurst J, Wismeijer D, De Bruyn H, Tahmaseb A. Current state of the art of computer-guided implant surgery. Periodontol 2000. 2017;73(1):121-133. https://dx.doi. org/10.1111/prd.12175

24. Moraschini V, Velloso G, Luz D, Barboza EP. Implant survival rates, marginal bone level changes, and complications in fullmouth rehabilitation with flapless computer-guided surgery: A systematic review and meta-analysis. Int J Oral Maxillofac Surg. 2015 Jul;44(7):892-901. https://dx.doi.org/10.1016/j. ijom.2015.02.013

25. Checchi V, Bertani P, Generali P, Generali L. Computer-guided implant placement in contact with root remnants in the esthetic area. Quintessence Int. 2021;52(2):132-137. https:// dx.doi.org/ 10.3290/j.qi.a45432

Received on: 4/9/2020

Final version resubmitted on: 18/11/2020

Approved on: 16/12/2020 